\title{
TRIAL TECHNIQUE IN ANTITRUST CASES
}

\author{
WAITER L. RICE*
}

An antitrust trial is not fundamentally different from other trials. As a rule, however, it involves broader issues of fact and requires more preparation and greater proof, because the typical antitrust case attacks a combination of large industrial corporations and questions a course of business conduct deemed to be contrary to our competitive system and injurious to other industrial groups.

\section{Preparing Witnesses by Sworn Statements and Grand Jury Testimony}

Witnesses in an antitrust trial generally have a continuing business interest in the outcome of the suit. If they are competitors or customers of the defendants, it is only natural that they will consider their future relationships in the industry. This sometimes leads to a race for witnesses, in which the Government too frequently runs second. It is not uncommon to find that potential witnesses receive price concessions and unprecedented good treatment from the defendants between the time of filing and trying an antitrust suit. Occasionally the Government is deprived of witnesses because the defendants discover shortly before trial that they need such witnesses as "advisers" or "experts," and place them on their pay rolls under such labels.

Long before the commencement of trial the foundations for the introduction of evidence must be laid. Only the loosest sort of preparation can be satisfied by merely sending agents into the field to interview witnesses. It is essential that wherever feasible witnesses be committed by signed statements, preferably sworn statements.

It is the usual experience of prosecutors that the best prepared case is one which has had the benefit of a carefully planned grand jury proceeding. Through such a proceeding witnesses can be sworn, thoroughly probed, and placed on record. The transcript of grand jury testimony is available to Government counsel, but not to defendants except by court order, which is generally refused. ${ }^{1}$ Defendant's counsel

*A.B., 1925, University of Minnesota; LL.B., I928, Harvard University. Member of the New York and District of Columbia Bars. Special Assistant to the Attorney General in charge of the United States Government's suit under the Sherman Act against the Aluminum Company of America and 62 other defendants. Lecturer, George Washington University, I931-1932.

${ }^{1}$ In U. S. v. Garsson, 291 Fed. 646,649 (S. D. N. Y. 1923), Judge Learned Hand commented that defendants' right to inspect grand jury minutes "is said to lie in discretion, and perhaps it does, but no judge of this court has granted it, and I hope none ever will." See also U. S. v. Oley, 21 F. Supp. 28r 
will think twice before he calls as his witness a man who has given a sworn statement or testimony before a grand jury, especially if he does not have a transcript of the testimony. The probability of destroying a vulnerable witness by prior contradictory statements creates a hazard which experienced counsel prefer to avoid.

If the prosecutor has had the foresight to obtain prior statements from the individual defendants and their probable witnesses; he is apt to be far better equipped for effective cross-examination. For this reason it is a mistake to call only friendly witnesses and ignore hostile witnesses in the grand jury hearing. Reluctant or uncertain witnesses may develop into key witnesses when their statements are elicited in formal examination under oath. Although the prosecutor has great latitude in the grand jury room and may be tempted to fall into the habit of leading friendly witnesses and asking incompetent questions, this will tend only to mislead him as to the kind of answers he may expect at the trial where opposing counsel and the court will enforce the rules of evidence.

\section{Depositions and Interrogatories Before Trial}

In civil cases which do not have the benefit of prior sworn statements before a grand jury, the plaintiff's counsel may obtain much valuable evidence before trial by invoking the new "Rules of Civil Procedure," which became effective September I6, 1938.2 One of the principal contributions of the new rules is in liberalizing discovery and the taking of testimony before trial, matters covered in Rules $26-37$.

The moving party is more apt to be interested in a full disclosure of all relevant facts than is the defendant, who may be seeking to avoid liability either because the violation cannot be fully and convincingly proved or because his connection with it cannot be established by competent proof. Under such circumstances the Government prosecutor has every incentive to force the production of proof and liberalize the rules of procedure and the admissibility of evidence. The defense does not always have the same incentive, and it is therefore of primary importance that the prosecutor be equipped to remove obstructions to proof.

Under Rule 26 a party may take the testimony of any person either orally or on written interrogatories "for the purpose of discovery or for use as evidence." The scope of the deposition need not be defined in advance, but the court may limit its scope by order (Rule 30). Thus the burden is placed upon the party opposing the deposition.

(E. D. N. Y. 1937); Metzler v. U. S., 64 F. (2d) 203, 206 (C. C. A. 9th,'I933); U. S. v. American Medical Ass'n, 26 F. Supp. 429, 43 I (D. C. 1939).

For a further discussion of this point, see Lewin, The Conduct of Grand Jury Proceedings in Antitrust Cases, stupra, p. I21.

2 The new rules have not been in effect long enough to demonstrate fully their contribution to simplification of antitrust trials. The only Government antitrust case tried under these rules to date is the pending Aluminum monopoly trial, which commenced June $\mathrm{I}, 1938$, and is still in progress. U. S. v: Aluminum Company of America, S. D. N. Y., Eq. No. 85-73, filed April 23, 1937. In discussing the application of the rules to antitrust cases, reference will be made to the district judge's interpretations which are no longer in issue in the trial of that case. 
Such depositions may be used to contradict or impeach the witness at the trial. If the deponent is a party to the suit, the adverse party may use the deposition at the trial for any purpose. A party taking a deposition runs the hazard of having the deposition used against him in the event that it is unfavorable, but only if the witness is unavailable or "such exceptional circumstances exist as to make it desirable, in the interest of justice ... to allow the deposition to be used" (Rule 26 (d) (3)).

Under this rule a party incurs very little risk by probing;adverse parties or hostile witnesses residing in the vicinity of the court by taking depositions before trial. Under Rule 26 (f) the mere taking of a deposition does not make a person the witness of the party taking such testimony.

The value of a deposition may be destroyed by asking too many questions, be. cause Rule 26 (d) (4) provides: "If only part of a deposition is offered in evidence by a party, an adverse party may require him to introduce all of it which is relevant to the part introduced, and any party may introduce any other parts."

Written interrogatories may be served upon an adverse party to the suit, and answers may be required under oath (Rule 33). Such interrogatories are especially useful in complicated antitrust cases where it is necessary to elicit from the defendants statistical information regarding such matters as production, sales, prices, narrative statements of particular commercial transactions, and custody of important documents.

After the interrogatories have been answered, controversy may arise as to the extent of their use in an antitrust case, especially if there are numerous defendants with diverse interests. The answers are obviously competent evidence against the party answering on the theory of admissions. ${ }^{4}$ In the Aluminum monopoly trial Judge Caffey has held that the interrogatory answers of one defendant are not ad-

\footnotetext{
There has been diversity of authority on the question whether the party giving a deposition may introduce it if the party taking the deposition offers none of it. Cases holding that the deponent has no right to offer the deposition are: Southern Railway Co. v. Hayes, 183 Ala. 465, 472, 62 So. 874,876 (I913); Conway \& Reyburn v. Turner \& Woodruff, 8 Ark. 356, 362 (1848); Beem v. Farrell, 135 Iowa 670, II3 N. W. 509 (I907); Fugate \& Young v. Carter, 6 Mo. 267, 272 (1840); Vaughn \& Co. v. Garland, 38 Va. 25 I (1840); cf. Shober v. Whecler, II3 N. C. 370, 377, r8 S. E. 328, 329 (1893). Contra: Hadley v. Upshaw, 27 Texas 547, 549-550 (1864); S. V. Bachemin v. Widow A. Scheixnaydre, I6 La. Ann. 32 (186I); Standard Life \& Acc. Ins. Co. v. Tinney, 73 Miss. 726, 733-734, I9 So. 662, 664-665 (1896); Page v. Krekey, I7 N. Y. Supp. 764, 768 (1892), rev'd on other grounds 137 N. Y. 307,33 N. E. 3 II ( 1893 ).

Some states hold that if the interrogating party offers some of the answers to interrogatories, he need not offer others except those that are connected or are necessary to complete the answers offered: Allend v. Spokane Falls \& N. Ry. Co., 21 Wash. 324, 336, 58 Pac. 244, 247 (1899); Demelman v. Burton, 176 Mass. 363, 57 N. E. 665 (x900); see Freeman v. United Fruit Co., 223 Mass. 300, 304, II I N. E. 789, 791,792 (I916). Other states hold that if some of the answers are introduced by the interrogating party, the other side may insist that all be introduced: Calvert, et al. v. Calvert, $180 \mathrm{Ala} .105,108,60$ So. 26I, 26I (1912); Southern Railway Co. v. Hayes, 183 Ala. 465, 473, 62 So. 874, 876-877 (1913). The better view appears to be that the interrogating party who offers answers to interrogatories may contradict them by other evidence: MFarland v. Hunter, 35 Va. 489, 497 (1836); Vaughn \& Co. v. Garland, 38 V2. 25I (1840); Moore v. Palmer, I4 Wash. 134, 44 Pac. 142 (1896).

'See Federal Surety Co. v. City of Staunton, Ill., 29 F. (2d) 9, I4 (C. C. A. 5th, 1928). See also Coggey v. Bird, 209 Fed. 803,807 (C. C. A. 2d, rgr3); Pan American Co. v. U. S., 273 U. S. 456,499 (1927); Guardian Trust Co. v. Meyer, xg F. (2d) 186, I91 (C. C. A. 8th, 1927).
} 
missible against other defendants, the other defendants having had no opportunity for cross-examination.

Where interrogatories are addressed to corporations, it is advisable to conclude them with a final interrogatory asking that the individual supplying each answer be designated at the foot of such answer. This may be helpful not only in enabling the Government to determine readily whom to call as witnesses on particular questions that may arise during the trial, but also in placing the Government in a position to contradict or impeach witnesses by their own sworn answers.

\section{Tral Subpoenas}

A subpoena duces tecum may serve as the key to the principal source of evidence in a large antitrust trial which has not been preceded by a grand jury hearing. Many antitrust trials have been won by the documents subpoenaed from defendants. Although it may be true that "Conspirators do not go out upon the public highways and proclaim their purpose," 6 it is rare that one or more of the business men engaged in an antitrust conspiracy does not write damaging letters either to his fellow conspirators calling for action under their agreement or to his favorite customers explaining that he cannot grant certain concessions because of an understanding among the defendants. ${ }^{7}$ Such letters generally may be received in evidence against their authors as admissions and against other defendant-conspirators as declarations in furtherance of the conspiracy, assuming that a conspiracy has been alleged and proved by prima facie evidence. ${ }^{8}$

Under Rule 45 subpoenas are issued in blank, signed and sealed by the Clerk of Court, and the party may fill in a description of the documents required. On motion of the witness, a subpoena may be quashed if it is "unreasonable and oppressive." The rule thus requires the subpoenaed party to take the initiative in any contest on the validity of the subpoena.

A trial subpoena may be issued as soon as the trial date is fixed and may be made returnable on the first day of trial. The issuance of trial subpoenas should not await the commencement of trial if the documents subpoenaed are numerous, first, because it may provide the adverse party with the basis for a legitimate claim of hardship and unreasonableness which may be a good defense to a subpoena, and second, because it may not afford sufficient opportunity for adequate inspection of the documents without delaying the trial.

In the Sugar Institute case ${ }^{\theta}$ the Government served about 20 subpoenas duces tecum upon defendants, calling for the production of more than 500,000 documents.

\footnotetext{
${ }^{5}$ See also Montgomery v. Dillingham, II Miss. 647, 657 (1844); Stetson v. Wolcott, Is Gray 545 (Mass. 1860 ), where it is held that the answer of one defendant generally is not evidence against codefendants except in the case of joint liability.

'Marrash v. U. S., 168 Fed. 225, 229 (C. C. A. 2d, 1909).

The record in Sugar Institute v. U. S., 297 U. S. 553 (1936), contains hundreds of Government exhibits of this character.

${ }^{8}$ Hitchman Coal \& Coke Co. v. Mitchell, 245 U..S. 229, 249 (I917).

Supra note 7.
} 
The exhibits selected from these documents furnished the basis for most of the court's findings of unreasonable restraints of trade.

In the Aluminum case Government counsel spent several weeks preparing one subpoena addressed to the chief corporate defendant. It contained I84 items comprising 32 pages. The Aluminum Company moved to quash the subpoena on the ground that it was unreasonable in that it called for large classes of documents under broad subject headings covering periods as long as fifty years. The motion was accompanied by an affidavit stating that it would require a search through four lineal miles of files containing perhaps 50,000,000 documents. The court allowed I74 of the I84 items of the subpoena, applying the rule that such a subpoena is valid if each item is reasonably limited as to (I) time, (2) parties, and (3) subject matter. ${ }^{10}$ Each item of this subpoena sought carefully but broadly to define the subject matter of the documents desired, the classes of persons who were parties to the documents, and the period of time covered. Virtually none of the documents had been seen by representatives of the Government. Although the documents produced were so voluminous that they weighed several thousand pounds and required the full time of four Government representatives working for one month to make a rough selection of 16,000 documents deemed worthy of photostating, the court felt bound by the decisions cited to allow each subpoena item which could be shown to be relevant to the issues raised in the pleadings. Before trial the court heard arguments as to the scope of the issues and the "probable materiality" of the documents subpoenaed. Each item of the subpoena was subjected to scrutiny and compared with the allegations of the bill of complaint to ascertain whether there was a probability that the documents called for were material to the charges.

In this connection it may be noted that the pleadings not only define the scope of the issues to be tried but also may restrict a party's right to subpoena documents and compel answers to interrogatories. With this in mind, the bill of complaint in an antitrust suit should be both broad and specific. Depending on the individual taste of the judge, the prosecutor may have occasion to rely either upon the broad allegations of monopolistic or restraining practices charged against the defendants, or upon the specific allegations describing particular transactions complained of, or both, to support his demand for documents and answers to interrogatories.

Inasmuch as a subpoena order operates in personam, it may require the person served to produce any books or records in his custody, even though he has to go outside the United States to produce them. ${ }^{11}$ In the Aluminum case, the Government

${ }^{10}$ Brown v. U. S., 276 U. S. 134, I43 (1928); Nelson v. U. S., 201 U. S. 92, 99-ror (1906); Consolidated Rendering Co. v. Vermont, 207 U. S. 54r, 553-554 (1908); Hammond Packing Co: v. Arkansas, 212 U. S. 322 (rg09); Wilson v. U. S., 221 U. S. $36 \mathrm{I}, 376$ (I9II); Whecler v. U. S., 226 U. S. 478, 489 (1913).

- ${ }^{12}$ Under $\S \mathrm{r}_{3}$ of the Clayton Act subpoenas "may run into any other district," provided that in civil cases where the subpoena is to be served more than yoo miles from the seat of the court, permission be obtained from the court "upon proper application and cause shown." Documents may be subpoenaed from any place in the United States, and even abroadif the court has jurisdiction over the custodian of the documents. See Consolidated Rendering Co. v. Vermont, 207 U. S. 54r, 552 (1908); Hammond 
subpoenaed important documents relating to an international combination, alleged to be fixing prices, from the defendant Aluminium, Limited, a Canadian corporation having an office in New York. The documents had to be brought from Canada and other foreign countries. The defendant did not attack the subpoena, perhaps because the trial court had previously sustained interrogatories which required it to obtain information from its foreign offices and through its foreign subsidiaries. ${ }^{12}$

\section{Inspection of Subpoenaed Documents}

When a subpoena has been sustained, only half of the battle to obtain access to the documents has been won, for a subpoena is merely an order requiring that the person subpoenaed "produce," i.e., bring into court, the designated documents which are in his custody. Until further order of court, he has no obligation to turn them over to opposing counsel. Under the old federal practice, at least prior to the enactment of Equity Rule $5^{8,},{ }^{13}$ a defendant called upon to produce numerous documents, the specific contents of which were unknown to the plaintiff, could cause great embarrassment to his opponent by merely bringing the documents into court and refusing to permit inspection. They could not be offered in evidence until they were properly identified by a competent witness and shown to be relevant, and it was awkward to attempt this without prior inspection of the documents. New Rule 34, however, provides that upon motion of any party showing good cause, the court

may order any party to produce and permit the inspection and copying or photographing, by or on behalf of the moving party, of any designated documents, papers, books, accounts, letters, photographs, objects, or tangible things, not privileged, which constitute or contain evidence material to any matter involved in the action and which are in his possession, custody, or control.

Under this rule photostat copies may be obtained before trial. Controversy, however, will arise in connection with the requirement that the documents must "constitute or contain evidence material" to the matter involved in the suit. If the person subpoenaed claims that the documents do not contain material evidence, how is this issue to be determined, and when?

Packing Co. v. Arkansas, 212 U. S. 322, 348 (r909); Trees v. Glenn, 319 Pa. 487, 490-49I (I935); Gemson v. Perreault, 20I App. Div. 649, I94 N. Y. Supp. 618 (1922); cf. The Salton Sea Cases, I72 Fed. 792 (C. C. A. 9th, I909), cert. denied, 215 U. S. 603; Madden v. Rosseter, II 4 N. Y. Misc. 4I6, r87 N. Y. Supp. 462 (I92I), aff'd, I96 App. Div. 914, I87 N. Y. Supp. 943 (I92I); (I908) 2 I HARv. L. REv. 354 .

${ }^{12}$ A foreign corporation over which our courts can obtain juriediction is accountable for acts done abroad and operative in the United States even though lawful abroad. U. S. v. American Tobacco Co., 221 U. S. I06, I85 (I9II); U. S. v. Sisal Sales Corp., 274 U. S. 268 (I927); U. S. v. Nord Deutscher Lloyd, 223 U. S. 512, 5I7-5I8 (I9I2); U. S. v. Bowman, 260 U. S. 94, 10I-102 (I922); U. S. v. Hamburg-Amer. P. F. A. Gesellschaft, 200 Fed. 806,807 (C. C. S. D. N. Y. 19II).

${ }^{18}$ Equity Rule 58 authorized "such orders as may be appropriate to . . . effect the inspection or production of documents in the possession of either party and containing evidence material to the cause of action." Under this rule the court could order inspection of documents when custody or control had been admitted of record or established by' answers to interrogatories. Pressed Steel Car Co. v. Union Pac. R. Co., 241 Fed. 964,967 (S. D. N. Y. 1917), per Learned Hand, J.; Dixie Drinking Cup Co. v. Paper Utilities Co., 5 F. (2d) 322, 324 (E. D. N. Y. I925). 
In the Aluminum trial these questions were squarely presented. The Government urged a liberal right of inspection under Rule 34. It argued that after a subpoena had been sustained on the theory that the documents subpoenaed were "probably material," it should have the right to inspect them in order to select and coordinate those to be offered. It was urged that until a party had seen the documents, he was hardly in a position to argue the ultimate materiality of any particular document. It was pointed out that upon defendant's assertion that the documents do not contain material evidence, the trial judge would be placed in the position of deciding this vital issue without the benefit of an adequate argument by plaintiff's counsel, who might be able to demonstrate the specific relationship of each document to other evidence to be offered. It was also suggested that the parties would be discouraged from invoking Rule 34 if it imposed upon the presiding judge the tedious burden of undertaking a preliminary inspection of each document subpoenaed, many of which could be eliminated by counsel's inspection. The trial judge, however, interpreted Rule 34 as requiring that, where the question of materiality is disputed, the judge must "examine every document before determining ... whether it may properly be inspected by the Government."14 He rejected the Government's contention "that the question of materiality is determinable by mere examination of the face of the subpoena" considered in the light of the pleadings and the testimony then in the record.

The right of inspection of documents before trial is of especial importance in a civil antitrust case because (I) the documents are apt to be so numerous as to require selection and classification, and (2) it is impracticable, boresome and undramatic to attempt to make any selection of documents during the formal examination of a witness on the stand. Although a trial subpoena may not be used to initiate a "fishing excursion, ${ }^{16}$ as perhaps may a grand jury subpoena, ${ }^{18}$ it is obvious that a selection from voluminous documents subpoenaed will almost always be necessary.

In some jurisdictions a party may be penalized by inspecting unfavorable documents subpoenaed from his opponent. In the Southern District of New York it was held in I89r that "If a party inspect a document produced by his adversary in response to a subpoena duces tecum issued by him, such document may be admitted as evidence for his adversary if he himself declines to put it in."17 It is suggested that a proper interpretation of Rule 34 would permit inspection without the hazard of any such penalty; otherwise the privilege of inspection is conditioned and discouraged.

\section{Short-cut in Authenticating Documents}

Rule 36, providing for the admission of genuineness of documents, may serve to greatly expedite the trial where a large number of documents are to be offered in

16 U. S. v. Aluminum Company of America, 26 F. Supp. 71 r, 712-7x3 (S. D. N. Y. 1939).

${ }^{15}$ U. S. v. Terminal R. Ass'n, 154 Fed. 268 (C. C. E. D. Mo. I907); General Finance Corp. v. New York State Rys., I F. Supp. 381, 382 (W. D. N. Y. 1931).

${ }^{10}$ U. S. v. American Tobacco Co., 146 Fed. 557 (C. C. S. D. N. Y. 1906).

${ }^{27}$ Edison Electric Light Co. v. U. S. Electric Lighting Co., 45 Fed. 55, 59 (S. D. N. Y. 189x). A later case, however, has thrown doube upon this doctrine. Worrall v. Davis Coal \& Coke Co, II3 Fed. 549,557 (S. D. N. Y. 1902). In the New York state courts the rule has been entirely cast aside. Smith v. Rentz, 131 N. Y. 169,30 N. E. $54(1892)$. 
evidence. Under this rule, a party may serve upon his opponent, at any time after the pleadings are closed, "a written request for the admission by the latter of the genuineness of any relevant documents described in and exhibited with the request or of the truth of any relevant matters of fact set forth therein." Unless the opponent submits a sworn statement within ten days "either denying specifically the matters of which an admission is requested or setting forth in detail the reasons why he cannot truthfully either admit or deny those matters," each of the matters is considered admitted. This virtually shifts the burden of establishing the genuineness of documents.

Previous to the enactment of this rule a party could maneuver his opponent into calling doubtful or adverse witnesses to authenticate documents, and then obtain the benefit of a cross-examination on the subject matter of the documents. ${ }^{18}$ Frequently this discouraged a litigant from relying upon documents which had to be introduced through hostile witnesses. Now the issue of authenticity is disposed of between the parties before trial or out of court during the trial, wherever the issue cannot reasonably be in dispute.

\section{Chorce of Trial Method}

The parties to a civil antitrust suit, especially the Government, have unusual freedom of choice as to how and where the case should be tried. The venue may be laid in any district where any one of the defendants is an "inhabitant". or "may be found or transacts business." Defendants not found in the district may be summoned from other districts "whether they reside in the district in which the court is held or not."20

After venue has been determined, the question still remains as to how the case should be tried. An antitrust case brought by the Government in a court of equity

is There is room for difference of opinion on the question whether a witness may be cross-examined on the entire subject matter of a document which he merely authenticates on direct examination. Beal v. Nichols, 2 Gray 262 (Mass. I854). But $c f$. Goodno v. Hotchkiss, 88 Conn. 655, 92 Atl. 419 (1914). There is some basis for the contention that a witness who testifies to the sole fact that he signed and sent a letter can be cross-examined only on that fact and not on the letter's contents. Mine \& Smelter Supply Co. v. Parke \& Lacy Co., ro7 Fed. 88x, 883-884 (C. C. A. 8th, I90x); Seymour v. Malcolm MCDonald Lumber Co., 58 Fed. 957, 959-960 (C. C. A. 6th, I893). Cf. Acolian Co. v. Standard Music Roll Co., 176 Fed. 81r (C. C. N. J. 1910); Montgomery v. Aetna Life Ins. Co., 97 Fed. 913, 916 (C. C. A. 6th, I899); see Note (1920) 7 A. L. R. III6. Counsel may better urge this theory of limited cross-examination if he defers his offer of the document until the witness has left the stand, for then he can argue that the direct examination was restricted to the bare testimony that the witness signed and sent the letter and that the cross-examination should not go further.

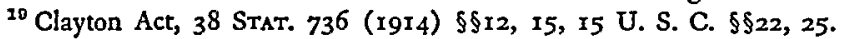

${ }^{20}$ Sherman Act, 26 STAт. 209 (1890) \$5, 15 U. S. C. \$5; Clayton Act, supra note 19, \$15. See U. S. v. Aluminum Company of America, 20 F. Supp. I3 (S. D. N. Y. 1937), holding even a Canadian corporation could be summoned to answer charges in the United States where it had an office and "transacted business." In Standard Oil Co. v. U. S., 22 I U. S. I, 43-44, 46 (I9II), only one corporation of the 7I corporate and seven individual defendants resided in the Eastern District of Missouri where the suit was brought, but the Supreme Court overruled objections to the venue. For a strict application of the requirements of venue, see the recent concurring opinion of Circuit Judge Sparks in U. S. v. SoconyVacuum Oil Co., Inc. ("Madison Oil Case") I05 F. (2d) 809, 839 (C. C. A. 7th, 1939), where it was said that the Western District of Wisconsin was not a proper venue because defendants' joint purchases of oil to effectuate the price-fixing conspiracy were made entirely outside the district, although sales were made within the district. 
may be tried before either (I) a United States District Judge, or (2) a special "Expedition Court" comprising all of the available circuit judges within the circuit, or (3) a special master or examiner designated by the court.

If the Attorney General files an expediting certificate certifying that "in his opinion, the case is of general public importance," the case is given precedence and "assigned for hearing at the earliest practicable day, before not less. than three of the circuit judges." 21 Such expediting certificates have been filed in only 29 antitrust cases since the enactment of the Expediting Act in $1903 .{ }^{22}$

The statute contains no express limitation as to when the expediting certificate must be filed. Whether it could be filed after a trial commences and thereby immediately transfer the cause from the district judge to the Expedition Court has never been squarely adjudicated. ${ }^{23}$ There might be circumstances of extreme delay where the Government would be justified in forcing a speedy determination by invoking the Expediting Act after the evidence has been submitted to the district judge. Or a

21 Expediting Act, 32 STAT. 823 (I903) \$I, I5 U. S. C. $\$ 28$.

${ }^{22}$ Most of these expediting certificates were filed during the period from I906 to 1916: Northern Securities v. U. S., I20 Fed. 72 I (C. C. D. Minn. 1903), 193 U. S. 197 (1904); U. S. v. Terminal R. R. Ass'n, 224 U. S. 383 (1905) (Ex parte United States, 226, U. S. 420 (1913), grew out of the Terminal R. R. Ass'n case); U. S. v. Standard Oil Co., 221 U. S. I (Igo6); U. S. v. American Tobacco Co., 22 r U. S. 106 (1907); U. S. v. New York, N. H. \& H. R. Co., 165 Fed. 742 (C. C. Mass. 1908); U. S. v. E. I. du Pont de Nemours \& Co., I88 Fed. I27 (C. C. D. Del. rgrr); U. S. v. Periodical Clearing House, I D. \& J. 287 (S. D. N. Y. I9II); U. S. v. Union Pac. R. Co., I88 Fed. 102 (C. C. D. Utah, rgrr), 226 U. S. 6r, 470 (IgI2); U. S. v. U. S. Steel Corp., 240 U. S. 442 (Igri); U. S. v. Kellogg Corn Flake Co., 222 Fed. 725 (E. D. Mich. 1912); U. S. v. Lake Shore \& M. S. Ry. Co., 203 Fed. 295 (S. D. Ohio, I912); U. S. v. Delaware, L. \& W. R. R., 238 U. S. 516 (1913); U. S. v. Great Lakes Towing Co., 208 Fed. 733 (N. D. Ohio, 1913), 245 U. S. 675 (1917); U. S. v. Reading Co., 253 U. S. 26 (1913); U. S. v. Eastern States Retail Lumber Dealers' Ass'n, 234 U. S. 600 (19r4); U. S. v. Hamburg-American S. S. Line, 216 Fed. 97 I (S. D. N. Y. 1914), 239 U. S. 466; U. S. v. International Harvester Co., 214 Fed. 987 (D. Minn. I9I4), 248 U. S. 587 (I9I8); U. S. v. Keystone Watch Case Co., 218 Fed. 502 (E. D. Pa. I915); U. S. v. Prince Line (American-Asiatic S. S. Ass'n, Ltd.), 220 Fed. 230 (S. D. N. Y. 1915), 242 U. S. 537 (1917); U. S. v. Quaker Oats Co., 232 Fed. 499 (N. D. Ill. I916); U. S. v. United Shoe Machinery Co., 247 U\& S. 32 (1918); U. S. v. New England Fish Exchange, 258 Fed. 732 (D. Mass. I9r9); U. S. v. Southern Pine Ass'n (E. D. Mo. 1921, unreported); U. S. v. N. Y. Coffee \& Sugar Exchange, 263 U. S. 6II (1924); U. S. v. Jeffrey Mfg. Co. (S. D. Ohio, 1925, unreported); U. S. v. Standard Oil Co. of Indiana, 33 F. (2d) 6r7 (N. D. Ill. 1929); U. S. v. Standard Oil Co. of N. J. (Vacuum Co.), 47 F. (2d) 288 (E. D. Mo. 193 I), a new expediting certificate was filed in this case; Appalachian Coals, Inc. v. U. S., 288 U. S. 344 (1932); U. S. v. Aluminum Company of America, 20 F. Supp. 608 (D. C. Pa. r937), aff'd, Aluminum Company of America v. U. S., 302 U. S. 230 (1937).

${ }^{23}$ Perhaps the nearest approach to this occurred when the defendants in the Alumintrm suit, which was filed in New York in 1937, obtained a temporary injunction in the Western District of Pennsylvania against Government counsel, restraining them from proceeding with the New York suit on the ground that the Government had filed a similar suit and had obtained a consent decree in Pennsylvania in Igrz. After a trial before the district judge in Pennsylvania, resulting in a temporary injunction against Government counsel, the Attorney General filed an expediting certificate in that district, certifying that the proceeding in Pennsylvania (which was ancillary to the I 912 suit in that district) had become of general public importance. Thereupon the circuit judges of the third circuit were convened as a special Expedition Court. Over defendants' objection, their application for a permanent injunction against Government counsel was tried before the Expedition Court, which held that it had jurisdiction despite the fact that the proceedings had commenced and a preliminary trial had been held before the district judge. U. S. v. Aluminum Company of America, 20 F. Supp. 608 (W. D. Pa. 1937). The judgment of the Expedition Court vacating the temporary injunction and denying a permanent injunction against Government counsel was affirmed by the Supreme Court. Aluminum Company of America v. U. S., 302 U. S. 230 (I937). 
situation might arise where the district judge becomes incapacitated or dies after the testimony has been submitted but before judgment. In either of these events, it would seem that the Expedition Court might properly expedite its own proceeding by accepting the record made before the district judge and hearing argument based upon such record and any supplementary evidence which the parties might present to a specially appointed master or examiner.

The choice between a district judge and an Expedition Court might be governed by the nature of the evidence to be offered, as much as by the desire for expedition. If the testimony is to be lengthy, it is almost certain that the Expedition Court will designate a special master or examiner to take the proof and report it to the court. It is doubtful whether such procedure expedites the trial of the issues, because the case must be fully argued before the Expedition Court at a separate hearing after the master has made his report. However, such a proceeding gives the parties the benefit of an initial adjudication of the facts by a court of three or more judges. A number of the most important cases in the trust-busting campaign of President Theodore Roosevelt were tried in this way. ${ }^{24}$ In the more recent Appalachian Coals case ${ }^{25}$ the testimony was taken before the Expedition Court itself.

If the testimony to be offered is of a sensational character, such as that presented in the poultry racket case, ${ }^{26}$ where it was important for the trial judge to observe the obvious intimidation of witnesses, there can be little doubt that the Government would lose a great advantage if the testimony were taken before a special master.

On the other hand, if the abuses complained of are not sensational and the demeanor of the witness not significant, the Government may gain an advantage by presenting the evidence before a special master and thereby subordinating the facts to the questions of law when the case is argued before the court. Also if the obstructions to technical proof are great, they may be minimized by taking testimony before a special master or examiner. The usual tendency in such a proceeding, as in an administrative hearing, is for counsel mutually to apply the rules of admissibility liberally, whereas in a trial before a judge who is in a position to rule forthwith on admissibility of proof, the tendency is to require strict proof and to take advantage of technical rules of evidence.

\section{The Opening Statement}

An opening statement should be a definite understatement of the facts which the plaintiff proposes to prove, whether the case is a criminal prosecution before a jury

\footnotetext{
"I In Standard Oil Co. v. U. S., 22I U. S. I (IgII) and U. S. v. American Tobacco Co., 22I U. S. I06 (IgII), the testimony was taken before special examiners appointed by the court with authority to take testimony in various parts of the country. In the antitrust suit against the paper industry, a special examiner was appointed with authority to take testimony both within and without the District of Minnesota. See Nelson v. U. S., 201 U. S. 92 (Ig06); Alexander v. U. S., 20 I U. S. II7 (I906). The proceeding arising out of the Socony-Vacuum consolidation in I93I under the old Standard Oil decree was argued before an Expedition Court sitting in the Eastern District of Missouri, which had appointed a special master to take the testimony in New York, 47, F. (2d) 288.

${ }^{28}$ U. S. v. Appalachian Coals, Inc., I F. Supp. 339 (W. D. Va. 1932); Appalachian Coals, Inc. v. U. S., 288 U. S. 344 (r933).

${ }^{20}$ Local 167 v. U. S., 29 I U. S. 293 (1934).
} 
or an equity suit before a judge. Superlatives, even though warranted, should be used sparingly at this stage of the trial.

In a criminal prosecution there is real danger of reversible error in opening statements discussing extraneous facts not in' issue or facts which cannot reasonably be proved by competent evidence. In all cases an exaggerated opening not only destroys the court's confidence in counsel but also commits him to an unnecessarily high standard of proof. If the proof falls short of the prosecutor's claim in his opening, a judge as well as a jury has a tendency to conclude that the proof has also fallen short of establishing a violation of law. On the other hand, if the proof surpasses the opening statement, the natural inference is that the plaintiff has more than proved his case.

It is neither permissible nor wise to indulge in argument in an opening. The function of an opening is to outline the issues and the evidence to be offered. It should lay a simple foundation for the evidence and for the conclusions which the party will seek to draw from the evidence. It affords counsel an opportunity, which he may not have again until summation, to show the relationship between items of evidence where the connection will not be apparent during the formal presentation of evidence unaccompanied by comment or argument.

\section{Selection of WitNesses}

Complaining witnesses are the backbone of an antitrust trial. Even though the issues present a clear-cut question of law and do not require the testimony of witnesses who have been injured by the alleged violations, the plaintiff's case will invite little sympathy from either a judge or a jury unless it appears that someone has been hurt or is about to be hurt by the violations. Without vigorous complaining witnesses, the Government's case tends to become academic and technical, and the court, in applying the "rule of reason," may reach out to find a business excuse for the course of conduct challenged by the Government. ${ }^{27}$

Even in case a suit were to be initiated by the Government without complaints from the industry, it would be the prosecutor's duty to canvass the industry in order to find witnesses who have legitimate complaints. If a cause of action has merit, it is rare that there are not a substantial number of members of the industry who have bona fide complaints which may be presented in the form of competent testimony showing how their business opportunities have been or will be injured by defendants' practices. Most of such potential complainants are not crusaders and do not submit complaints until they are solicited.

In a civil case it is often desirable to call some of the defendants to the witness stand early in the trial, whether the prosecutor has the benefit of their prior signed statements or not. If the Government's witnesses make out a strong case, the defendants are very likely to be called in any event as witnesses for the defense. There

${ }^{27}$ See Appalachian Coals, Inc. v. U. S., 288 U. S. 344 (1933). 
are certain advantages in forcing their testimony at an early stage of the trial when they do not know precisely what the Government's witnesses will testify.

Furthermore, the hazard involved in calling an adverse party has been minimized. Under Rule 43 (b) of the new Rules of Civil Procedure, "a party may call an adverse party . . . and interrogate him by leading questions and contradict and impeach him in all respects as if he had been called by the adverse party, and the witness thus called may be contradicted and impeached by or on behalf of the adverse party also, and may be cross-examined by the adverse party only upon the subject matter of his examination in chief."

Rule 43 (b) was given a strict interpretation in the Aluminum trial, where the Government called one of the individual defendants as a witness and proceeded to cross-examine him. Other defendants objected to this method of examination, and urged that his testimony in so far as it was received against them must be elicited in the orthodox form of a direct examination. The Government took the position that this would defeat the liberalizing intent of the rule as applied to antitrust cases, where there are many defendants and the evidence is needed against all of them. It argued that the true intent of the rule was to permit cross-examination of a witness who is "adverse" to the party calling him, and that the adverse relationship between the witness and the party calling him should establish the method of examination. The witness being one of the defendants, it was contended that the Government should have the right to cross-examine and that any competent and relevant evidence elicited in this fashion should be received not only against him but against all defendants on trial. However, when objections to questions calling for conclusions were raised simultaneously by the witness' counsel and by counsel for other defendants, the trial judge frequently overruled the witness' counsel's objection but sustained the objection of other defendants, apparently on the theory that the witness was to be considered "an adverse party" only as between the Government and himself, and not as between the Government and other co-defendants. The result was that part of this evidence was received against the witness but not against other defendants.

\section{Strategic Presentation of Strong Points}

Sometimes in a trial before a judge, and almost always in a trial before a jury, a significant point is subordinated in importance and may even pass unnoticed if counsel has not taken the precaution to build it up.

The strongest victory frequently is one which has been won after a contest. When a significant fact is bitterly contested by opposing counsel, and then established by incontrovertible proof, it assumes its proper importance in the case. Therefore, when counsel is confident that he can ultimately prove an important point by conclusive evidence, he may prefer to invite a contest before attempting to clinch the point.

The order of proof is primarily a matter of common sense. Wherever an issue of fact is to be presented by a series of witnesses and documentary evidence, the 
most effective order of proof may be: (I) the weaker witnesses, (2) the stronger witnesses, and (3) the documentary proof. The preliminary appearance of the weaker witnesses invites a challenge. The opposing counsel, who does not know what proof will follow the weaker witnesses, cannot afford to forego a vigorous cross-examination of them. By cross-examining he disputes the issue, and this gives rise to the inference, particularly before a jury, that the issue is one worth disputing.

If opposing counsel could anticipate that his adversary will later be in a position to establish the point decisively, he would of course take a different approach, perhaps conceding the fact and arguing that it is irrelevant or negated by some other fact.

It is of course expedient to have a second line of trenches in the defense of a case, but a litigant is very likely to suffer casualties in withdrawing from the position which he has set up as his first line of trenches.

\section{io. Cross-examination of Defendants' Witnesses}

The average defendant in an antitrust case involving large business interests ordinarily avoids deliberate falsehoods on the witness stand. Scruples apart, he is likely to be intelligent enough to recognize the danger of being trapped in a falsehood. This does not mean that he will not color or exaggerate facts.

An antitrust case affords unusual opportunities for expression of opinion by defendants' witnesses as to the effect of business practices which may be in issue. It is not uncommon for the defense to call a witness with the hope that on crossexamination he may seize an opportunity to testify to the conclusion that the restraint or monopolistic practice under attack does not lessen competition. Ordinarily this is a conclusion which the court will be called upon to determine and such testimony would not be permitted on direct examination. An unguarded cross-examination may invite the conclusion. For this reason the cross-examination is apt to be far more productive and less dangerous if it is confined to specific questions designed to show what happened in concrete transactions. Such cross-examination may well be devoted largely to confronting the witness with documentary evidence, especially his own correspondence and memoranda.

In the racketeering type of antitrust case such as those involving the Illinois railroad bombing, ${ }^{28}$ trucking, ${ }^{29}$ fur, ${ }^{30}$ and the poultry racket, ${ }^{81}$ the witnesses are more naïve, and more susceptible to obvious contradictions in their cross-examination.

Where an inexperienced witness appears too ready to identify an individual, he can sometimes be maneuvered into revealing his falsity. An instance of this occurred in the Schechter ${ }^{32}$ trial in 1934. Government witnesses had testified that on June 28, 1934, inspectors of the NRA Code Authority had been intimidated by the

28 U. S. v. Anderson, ror F. (2d) 325 (C. C. A. 7th, 1939); cert. denied, 59 Sup. Ct. 822 (1939).

${ }^{20}$ U. S. v. McGlone, I9 F. Supp. 285 (E. D. Pa. I937).

${ }^{80}$ U. S. v. Shapiro, 103 F. (2d) 775 (C. C. A. 2d, 1939).

${ }^{21}$ Local 167 v. U. S., 291 U. S. 293 (1934).

${ }^{32}$ Schechter Corp. v. U. S., 295 U. S. 495 (1935). 
Schechter brothers when they endeavoured to inspect the Schechter market. They testified that one of the Schechters held an ax in his hand and said, "I'll bury it in your skull. You'll never get out of this place alive." To contradict this testimony, the defendants called two orthodox Jewish slaughterers, who testified that they were working in the Schechter market when the inspectors arrived and that they saw no threats or violence. The first one testified that he remembered the inspector, that he wore a badge, and that he would recognize him if he saw him. On crossexamination he was maneuvered into identifying a stranger as the inspector. The cross-examination commenced as follows:

- Q. Do you remember the inspector with the badge? A. Yes, sir.

Q. Would you recognize him if you saw him again? A. If I see him-

Q. Look around the court room and see if you see him. A. I can't tell.

At this point the Government prosecutor selected at random from the spectators sitting in the court room a man about the same size and complexion as the inspector, and asked him to stand up. The cross-examination continued as follows:

Q. Is this the man? A. I can't see.

Q. Come over here and take a look at him, is this the man here? A. That is him.

The astonished spectator, who had not been advised that he was to be used in this experiment, was asked by the trial judge to come forward and stand before the jury. The prosecutor then explained that this man was a stranger and that his only purpose was to see whether the witness on the stand would identify the first man who was pointed out to him.

The second witness, who had been kept outside the court room while his associate testified, parroted the first, using almost identical language. Although he boasted that he was religious and devoted himself only to matters "holy," he discredited himself by denying that he had discussed the subject matter of his testimony with his associate, his counsel or anyone else. It is a remarkable fact that the average unsophisticated witness assumes that it is improper to discuss the facts with counsel before taking the stand and becomes an easy victim to opposing counsel's question as to whether he has discussed the case before testifying. This particular witness afforded considerable amusement as he dressed up his denial in the following crossexamination:

Q. Did you talk about this case this morning? A. With who?

Q. With anybody. A. No.

Q. Did you ever talk to anybody about this case? A. No; I told you one time I am not interested in this case, and I didn't speak with nobody except the day was the counsel in the place and he says I have to come in this case for a witness, that is all.

Q. Did he tell you about the questions that he would ask you? A. No, not me; I only talk about what is holy.

Q. He didn't ask you any questions at all? A. No. I am too honest for that; he don't want to.

Q. He didn't ask you the questions that he would ask you on the stand? A. No. 
Q. Nobody asked you any questions? A. No, if somebody ask me I won't answer it, only if the Judge he is asking me I answer him.

Q. You didn't know what questions were going to be asked today? A. What they ask me, no. If the Judge will ask me I will answer it-

The Court: Did you know what they were going to ask here today? A. No.

Q. You didn't have any idea what they would ask you? A. I don't know.

When attention was called to the fact that he had testified in almost the same language as his associate who preceded him on the stand, it became apparent that, however "holy," he was not quite frank.

\section{ix. Infringement of Privilege Against Self-Incrimination}

Many verdicts in criminal cases have been reversed because the prosecution has infringed upon the defendants' constitutional privilege against self-incrimination. Through decades of interpretation, this privilege has been so far extended and so vigorously applied as to become one of the favorite loopholes for the escape of guilty defendants. It is uniformly held that any mention in the presence of the jury of the defendant's failure to testify constitutes an infringement upon his privilege not to testify and is ground for a mistrial. ${ }^{33}$.

In a trucking extortion case under the Federal Anti-Racketeering Act and the Sherman Act, tried in $19377^{34}$ the Government employed a method of calling attention to the defendants' failure to testify, which is permissible but perhaps near the danger point. During the summation to the jury, the prosecutor repeatedly pointed out that the testimony of the Government witnesses stood uncontradicted and that the defendants had not produced any witnesses to challenge the truth of the Government's testimony. This finally prompted defendants' counsel to move for the withdrawal of a juror and a mistrial. The judge ruled that this comment did not constitute fundamental error and denied the motion, but he warned the Government that it came very near to the danger zone. ${ }^{35}$

\footnotetext{
${ }^{33}$ The act of March 16,1878 , c. 37,20, STAT. 30,28 U. S. C. $\$ 632$, provides that in criminal cases the defendant "shall, at his own request but not otherwise, be a competent witness. And his failure to make such request shall not create any presumption against him." This statute prohibits comment by the prosecutor or by the court on the failure of a defendant to testify. Wilson v. U. S., I49 U. S. 60 (I893); see Reagan v. U. S., I57 U. S. $30 \mathrm{I}, 305$ (I895). The rule is a corollary of the presumption of the defendant's innocence. Linden v. U. S., 296 Fed. I04 (C. C. A. 3d, r924).

The statute prevents even an indirect reference to the failure of the defendant to testify. De Mayo v. U. S., 32 F. (2d) 472,475 (C. C. A. 8 th, 1929); see also Tingle v. U. S., 38 F. (2d) 573 (C. C. A. 8 th, r930). The test applied is whether the language used was "manifestly intended to be, or was ... of such character that the jury would naturally and necessarily take it to be a comment on the failure of the accused to testify." Morrison v. U. S., 6 F. (2d) $809,8 \mathrm{rI}$ (C. C. A. 8th, 1925). Sce also Robilio v. U. S., 29I Fed. 975,985 (C. C. A. 6th, 1923), cert. denied, 263 U. S. 716 (1923).

86 U. S. v. McGlone, ig F. Supp. 285 (D. Pa. 1937).

${ }^{85}$ A prosecutor may in final argument call to the attention of the jury the fact that the evidence for the Government is uncontradicted. To be objectionable, comment must refer to the failure of the defendant personally to testify. Rice v. U. S., 35 F. (2d) 689,694 (C. C. A. 2d, 1929), cert. denied, 281 U. S. 730 (I929); Slakoff v. U. S., 8 F. (2d) 9, Io (C. C. A. 3d, 1925); Lias v. U. S., 5I F. (2d) 215,

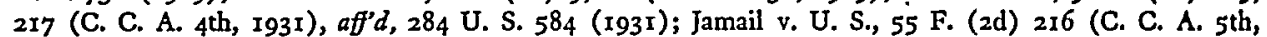
r932); Rinella v. U. S., 60 F. (2d) 216,218 (C. C. A. 7 th, '1932); Gargotta v. U. S., 77 F. (2d) 977
} 


\section{I2. Vicarious Admissions by Corporate Defendants}

An antitrust conspiracy is peculiarly susceptible to proof by admissions. Such admissions typically are of two kinds: (I) statements made by individual defendants or by representatives of corporate defendants engaged in transacting corporate business, and (2) declarations by co-conspirators made during the conspiracy and in furtherance of its objectives. Declarations in furtherance of the alleged conspiracy are not admissible until the court is satisfied by prima facie proof of the existence of the conspiracy and the participation of the declarant therein. ${ }^{36}$ In proving the prima facie case of conspiracy, admissions may be received against the individual defendants making the admissions and against corporate defendants which have authorized the admissions.

Vicarious admissions by representatives of corporate defendants present two questions: (I) Does the alleged representative have express or implied authority to speak for the corporation? (2) Was the admission made in the course of conducting corporate business, i.e., as part of the res gestae of a corporate act? If the preliminary evidence fails to support the affirmative of both of these propositions, the admission cannot be received against the corporation, although it may well be received against the individual making the admission if he is a defendant. This raises the practical and sometimes vitally important question of designating individuals as well as corporations as defendants in the suit. The Department of Justice has occasionally handicapped itself in the trial of antitrust conspiracy cases by limiting too narrowly its list of individual defendants, or sometimes by generously leaving out the individuals altogether and naming only the corporations as defendants. A magnanimous gesture of this character is rarely appreciated and is apt to multiply the problems of the prosecutor.

As a matter of strict legal principle, the admissibility of such vicarious admissions against corporate defendants should not be affected by the question whether the

(C. C. A. 8th, 1935); Hood v. U. S., 59 F. (2d) 153, 155 (C. C. A. roth, r932). But cf. Linden v. U. S., 296 Fed. 104, I06 (C. C. A. 3d, 1924 ).

It has been intimated that where defense counsel in argument criticizes the prosecutor for failure to call additional witnesses, the prosecutor may answer by informing the jury that the law prohibits the Government from calling defendants without their consent. Morgan v. U. S., 3I. F. (2d) 385,388 (C. C. A. 7th, 1929), cert. denied, 280 U. S. 556 (1929). But cf. McKnight v. U. S., I15 Fed. 972, 98I (C. C. A. 6th, I902).

A defendant may waive his immunity from comment by voluntarily testifying as to the merits of the case. Raffel v. U. S., 27 I U. S. 494 (1926). Where he so testifies, it is proper to call attention to detailed charges which he has not denied. Caminetti v. U. S., 242 U. S. $47^{\circ}, 494$ (1917); Carter v. U. S., 19 F. (2d) 43 r, 434 (C. C. A. 8th, r927); Le More v. U. S., 253 Fed. 887 (C. C. A. 5th, xgr8), cert. denied, 248 U. S. 586 (I918). But cf. Grantello v. U. S., 3 F. (2d) II7, I21 (C. C. A. 8th, 1924).

${ }^{36}$ Connecticut Mutual Life Ins. Co. v. Hillmon, I 88 U. S. 208, 2 I9 (1903); Boyle v. U. S., 259 Fed. 803,808 (C. C. A. 7th, I9r9); Winchester \& Partridge Mfg. Co. v. Creary, I I6 U. S. I6r, I66 (1885). The association of the alleged conspirators in the prosecution of the "common plan or enterprise" must be proved by independent evidence, but the illegality of the conspiracy may be proved by the declarations of the conspirators themselves. Hitchman Coal \& Coke Co. v. Mitchell, 245 U. S. 229, 249 (I9I7). The trial court, in its discretion, may at the outset receive declarations of an alleged conspirator subject to connection by later proof of conspiracy. Cohen v. U. S., I57 Fed. 65I, 655 (C. C. A. 2d, 1907). If the court can be persuaded to adopt this procedure it may prove especially advantageous to the prosecution. 
individual making the statement is also a defendant. But the practical difference is that the admission will come in against the individual if he is a defendant, and once the admission is in the record it makes so little difference whether it is received against the corporate defendant that defendants' counsel generally will not challenge the authority of the declarant to bind the corporation.

In the trial of United States v. Warner Bros. Pictures, Inc., et al., held in St. Louis in 1936, this practical consideration, plus the trial judge's unusual strictness in receiving vicarious admissions, led to a withdrawal of the suit against nine motion picture corporations after three weeks of trial, and the filing of a new suit in New York against the same corporations plus $3^{\mathrm{r}}$ individual defendants. District Judge Molyneaux, who presided at the trial, ruled that the admissions of Adolph Zukor, President and Chief Executive Officer of Paramount Pictures, Inc., could not be received in evidence against the Paramount Corporation without specific proof of Zukor's authority to speak for the corporation with respect to the distribution of films. Zukor was not named as an individual defendant in the St. Louis suit. In an effort to prove Zukor's authority to speak for the corporation, the Government called Charles D. Hilles, one of the trustees in bankruptcy of the Paramount Corporation. Hilles testified that Zukor had been President of Paramount, and continued in this position after the bankruptcy. He testified that Zukor had the title of "Chief Executive Officer" as well as President, that Zukor had been asked to concentrate on the production of pictures, that one Schaefer had been designated as General Manager to coordinate the work of distributing and exhibiting films, and that although Zukor worked chiefly on production, he was never forbidden from carrying on distribution.

The Government argued that Zukor's position as President and Chief Executive Officer gave him general supervisory jurisdiction and presumptive authority to speak for the corporation on matters of distribution of films. ${ }^{37}$ The Government had also offered proof that Zukor had joined with Schaefer in conferences with customers pertaining to the distribution of films. Nevertheless, Judge Molyneaux ruled that there was not sufficient proof that Zukor had authority to speak for the corporation on matters of distribution or that he was transacting corporate business when he and Schaefer presumed to discuss the marketing of pictures with customers. It was found to be impossible to meet such a high standard of preliminary proof. The testimony concerning Zukor's admissions to customers was stricken out. This encouraged defendants' counsel to make motions to strike out other conversations between Government witnesses and officers of Paramount and Warner Bros., on the theory that the officers making the admissions were merely expressing opinions

${ }^{87}$ Bassick v. Aetna Explosives Co., 246 Fed. 974, 987 (S. D. N. Y., 1917), quotes from Actna Explosives Co. v. Bassick, 176 App. Div. 582 , 163 N. Y. Supp. 917,921 (1917), in stating that "where a president of a trading or business corporation is given general management and control of its property, business, and affairs, the corporation is prima facie bound by contracts entered into by him in the name of the corporation, if the contracts are within the apparent power of the corporation." 
regarding past actions on the part of their corporations and were not affirmatively shown to be transacting corporate business. Most of these motions were granted.

Under these circumstances, the Government moved to dismiss "without prejudice" to its right to file a new suit. The motion was granted over defendants' objection. The defendants appealed to the Supreme Court, which held in a per curiam opinion $^{38}$ that the appeal should be dismissed and the decree of dismissal without prejudice should be affirmed, on the authority of earlier Supreme Court cases holding that a complainant in equity has the absolute right to dismiss his bill at any time before final decree unless some plain legal prejudice would result to the defendants other than the mere prospect of future litigation. ${ }^{39}$

While this appeal was pending, the Government filed a new suit against the same nine corporate defendants, plus $3^{\mathrm{r}}$ new individual defendants such as Zukor, as against whom the Government was prepared to prove admissions. ${ }^{40}$ This suit was settled by a practical arrangement under which the defendants undertook to guarantee contracts to the complaining witnesses for the exhibition of pictures in their theatres.

Prior testimony by corporate officials is occasionally offered in evidence as a vicarious admission binding upon the corporation. A statement made by an individual defendant is of course no less admissible against him because it was made in the form of sworn testimony. ${ }^{41}$ The more difficult question is whether prior testimony by an individual can be received as a vicarious admission, binding upon the corporation under any circumstances. The case involving the Doheny-Fall Teapot Dome fraud perhaps goes furthest on this point. ${ }^{42}$ There Doheny's testimony relating to past events before a Senate Committee investigating the Teapot Dome fraud was received in evidence against Pan American, because Doheny at that time was President and principal stockholder of the corporation and was presumably testifying "within the scope of his authority as an agent" explain the oil leases to the committee and thereby exculpate the corporation from suspicion of fraud. ${ }^{44}$

\section{I3. Proof of Competition}

Most antitrust trials involve the issue of the existence or nonexistence of competition,.and the question therefore arises as to how this issue may be proved. In the typical antitrust case the Government is endeavoring to show suppression of competition or an absence of competition following the imposition of the restraints, and the defendants are endeavoring to show the existence of vigorous competition. How-

${ }^{38}$ Warner Bros. Pictures, Inc. v. U. S., 298 U. S. 643 (1936).

${ }^{39}$ Pullman's Car Co. v. Transportation Co., 171 U. S. 138, I45-146 (1898); McGowan v. Columbia River Packers' Ass'n, 245 U. S. 352, 358 (Ig17); Ex parte Skinner \& Eddy Corp., 265 U. S. 86, 93-94 (1924); Jones v. Securities and Exchange Commission, 298 U. S. I (1936).

${ }^{10}$ U. S. v. Warner Bros. Pictures, Inc., S. D. N. Y. Eq. No. 82-206, petition filed Feb. 25, 1936.

${ }^{21}$ Coggey v. Bird, 209 Fed. 803,807 (C. C. A. 2d, r9r3).

12 Pan American Petroleum Co. v. U. S., 9 F. (2d) 76I, 768-769 (C. C. A. 9th, 1926), 273 U. S. 456,499 (1927).

${ }^{4} 9 \mathrm{~F}$. (2d) at 769 .

"See also Guardian Trust Co. v. Meyer, Ig F. (2d) I 86, I91, I92 (C. C. A. 8th, 1927). 
ever, the situation may be reversed in a trial under Section 7 of the Clayton Act, where the Government seeks to enjoin one corporation from acquiring the stock of a competing corporation. There the Government has the burden of proving the existence of competition between the two corporations.

The party endeavoring to establish the existence of competition is generally found on the affirmative of the question as to whether witnesses can testify to the conclusion that competition exists.

In the suit brought by the Government under the Clayton Act in 1935 to enjoin the merger of Republic Steel Corporation and Corrigan-McKinney Steel Company, the Government called a series of witnesses who testified that competition between the two corporations was intense, that they solicited orders for comparable steel products from the same customers, and that their salesmen engaged in rivalry to perform services for customers common to both steel companies. ${ }^{45}$ This proof was fortified by statistical exhibits showing the volume of production of each comparable steel product, the volume of sales in states where each marketed its products, lists of the customers common to both companies, percentages of the industry's various steel products produced and sold by each company, etc.

Generally, however, the extent of competition cannot be reduced to a mathematical formula. It is essentially a matter of opinion and judgment by people who have had occasion to study the operation of the industry. This leads to the question whether the existence of competition can be proved by mere conclusions of members of the trade. In the Trenton Potteries case, where the defendants sought to rebut the Government's proof of price fixing, the court would not permit defendants' witnesses to testify to the conclusion that competion was still intense, and this was sustained by the Supreme Court. ${ }^{48}$ A strict application of this rule would perhaps also preclude customers, economists or other Government witnesses from testifying to the conclusion that they had observed an absence of competition in the industry. The issue of competition then must be proved by analytical exhibits showing the competitive or non-competitive aspects of such statistical facts as production and sales and by testimony of people in the trade who can give concrete and specific evidence of the character of the bargaining between sellers and buyers and other manifestations of active rivalry for business.

${ }^{45}$ U. S. v. Republic Steel Corp., II F. Supp. II7 (N. D. Ohio, 1935). It is interesting to note that mere rivalry for orders is regarded as substantial competition worth preserving in an industry where virtually all other manifestations of competition, such as variation in prices and terms, have ccased. This of course is consistent with the principle that a concerted restraint upon prices and terms constitutes an unreasonable restraint of trade even though the members of the industry continue to engage in rivalry for customers' orders. See Sugar Institute v. U. S., 297 U. S. $553^{\prime}$ (r936), where the sugar refiners' concerted program of price reporting and suppression of competition in terms, quantity discounts, freight absorptions and other allowances to customers, was held to constitute an unreasonable restraint of trade despite the continued existence of intense rivalry among the refiners for orders.

${ }^{10}$ U. S. v. Trenton Potteries, 273 U. S. $392 \cdot(1927)$. In the Aluminum trial, Judge Caffey permitted the defendants to testify over the Government's objection that there was competition with the Aluminum Company of America from secondary aluminum, the copper and steel industry, and foreign producers. 